\title{
Karakterisasi Substrat dan Suhu Ekstrak Kasar Lipase Aspergillus Niger M1407
}

Amelia M. Salmon, Mellissa E. S. Ledo, Merpiseldin Nitsae

Fakultas Keguruan dan Ilmu Pendidikan, Universitas Kristen Artha Wacana, Indonesia, email: ameliasalmon05@gmail.com

Artikel Ini Telah Diseminarkan Pada Seminar Nasional Saintek Unimor 2019

\section{Article Info}

Article history:

Received 23 Oktober 2019

Received in revised form $31 \mathrm{Mei} 2020$

Accepted 2 Juni 2020

\section{DOI:}

https://doi.org/10.32938/slk.v3i1.1038

Keywords:

Aspergillus niger M1407,

karakterisasi,

substrat,

Eksrak kasar lipase

\begin{abstract}
Abstrak
Isolasi ekstrak kasar Aspergillus niger M1407 menggunakan medium tepung biji kesambi melalui solid state fermentation telah dilakukan sehingga perlu dilakukan karakterisasi substrat dan suhu untuk menentukan kondisi optimal reaksi enzim substrat ekstrak kasar lipase Aspergillus niger M1407.Penelitian ini bertujuan untuk mengetahui profil substrat dan suhu ekstrak kasar lipase Aspergillus nigerM1407, Penelitian ini dilakukan di laboratorium (mikrobiologi dan kimia) Program Studi Pendidikan Biologi Universitas Kristen Artha Wacana Kupang, pada bulan januari 2019 - maret 2019. Metode yang digunakan dalam penelitian ini terbagi menjadi empat tahapan yaitu pembuatan medium untuk isolat lipase Aspergillus niger M1407; pembuatan medium Solid-State Fermentation selama 7 hari; karakterisasi substrat menggunakan asam oleat +etanol dalam isooktan dan asam oleat + metanol dalam isooktan dan karakterisasi suhu pada variasi suhu $20^{\circ} \mathrm{C}, 30^{\circ} \mathrm{C}$ $40^{\circ} \mathrm{C}, 50^{\circ} \mathrm{C}$, dan $60^{\circ} \mathrm{C}$; serta pengujian Analisis aktivitas lipase menggunakan metode titrasi. Data yang di peroleh di analisis secara deskriptif kuantitatif. Hasil penelitian ini menunjukan bahwa aktivitas enzim ekstrak kasar lipase Aspergillus niger M1407 lebih baik pada substrat asam oleat dalam metanol yang memiliki aktivitas $200 \mathrm{U} / \mathrm{mL}$ sedangkan karakterisasi suhu, merupakan aktivitas ekstrak kasar lipase Aspergillus niger M1407 memiliki suhu optimum pada suhu $40^{\circ} \mathrm{C}$ dengan aktivitas enzim yaitu $580 \mathrm{u} / \mathrm{mL}$.
\end{abstract}

\section{Pendahuluan}

Lipase merupakan enzim yang memiliki peran penting dalam bioteknologi modern, dan terkenal memiliki aktivitas yang tinggi dalam reaksi hidrolisis dalam kimia sintesis. Lipase dapat berperan sebagai biokatalis untuk reaksireaksi hidrolisis, esterefikasi, alkoholisis, asidolisis (Murni dkk.,2011). Salah satu enzim yang mempunyai peranan penting dalam perkembangan bioteknologi adalah lipase. Enzim lipase juga berperan dalam produksi seperti produksi pestisida, pengolahan limbah, industri makanan (pembuatan roti dan keju), biosensor, detergen, industri kulit, pembuatan kertas, dan industri oleokimia (Handayani dkk.,2007).

Aspergillus niger merupakan jenis mikroba yang memiliki keunggulan, yaitu menghasilkan enzim ekstraseluler dengan aktivitas tinggi serta mudah dalam pemeliharaannya. Selain itu, secara ekonomi mikroba tersebut harus mudah didapat dengan harga yang murah, dan mampu berkembang pada media yang biayanya relatif murah serta ketersediaannya mudah didapatkan(Murni dkk., 2011).

Sumber enzim lipase, menurut Suhendra dkk.(2004) dalam Nurosid $d k k$, (2008) lipase dapat dihasilkan dari tanaman, hewan, manusia, yeast, jamur dan bakteri. Salah satu tanaman yang diketahui menghasilkan lipase adalah biji wijen (Sesamun indicum). Fadiloglu dan Erkemen, (2002) dalam Nurosid dkk.(2008) mengatakan bahwa pada manusia dan hewan, lipase yang dihasilkan terdapat pada kelenjar pankreas. Kelompok yeast yang dapat menghasilkan lipase adalah dari Candida rugosa, sedangkanMahadik dkk.(2002) dalam Nurosid dkk. (2008) menemukan bahwa kelompok jamur adalah Aspergillus niger dan Penicillum aurantiogriseum. Jospeh dkk.(2007) dalam Nurosid dkk.(2008) mengatakan bahwa kelompok bakteri, lipase dihasilkan dari genera Bacillus, Aeromonas, Pseudomonas, Alcaligenes, Arthrobacter, Chromobacterium, Serratia, Vibrio, Aeromonas, dan Staphyloccus

Berdasarkan penelitian sebelumnya yang dilakukan oleh Sele. (2014), ditemukan bahwa fungi lipolitik penghasil enzim lipase yang berhasil diisolasi dari biji kesambi adalah Aspergillus niger, Aspergillus flavus dan Penicilum sp. Dari penelitian tersebut di dapatkan fungi dengan kemampuan lipolitik terbaik, adalah Aspergillus niger yang telah diberikan kode M1407.

Substrat merupakan sumber nutrien utama bagi fungi. Nutrient-nutrien tersebut dapat dimanfaatkan sesudah fungi mengekskresi enzim-enzim ekstraseluler yang dapat mengurai senyawa-senyawa kompleks dari substrat tersebut menjadi senyawa-senyawa yang lebih sederhana (Gandjar dkk., 1999).
Pada suhu optimal, reaksi antara enzim dan substrat sangat efektif, sehingga pembentukan kompleks enzim substrat makin mudah dan produk yang terbentuk meningkat (Masfufatun,2011). Konsentrasi substrat berpengaruh terhadap kontak enzim-substrat, enzim-substrat memiliki spesifitas yang tinggi, apabila substrat cocok dengan enzim, maka kinerja enzim juga akan optimal (Aziz, 2012)

Setiap lipase berfungsi secara optimum pada suhu tertentu. Semakin tinggi suhu, menurunkan aktivitas. Lipase adalah protein, semakin tinggi suhu protein, inaktivasi lipase juga meningkat karena karena lipase akan terdenaturasi pada suhu tinggi (Winarno, 1998). Dalam penelitian Hidayat,dkk (2015) menemukan bahwa suhu optimum pada lipase A.niger $65 \mathrm{I} 6$ adalah suhu $40^{\circ} \mathrm{C}$

Bahan organik dari substrat digunakan oleh Aspergillus niger untuk aktivitas transport molekul, pemeliharaan struktur sel dan mobilitas sel. Aspergillus Niger bersifat toleran terhadap aktivitas air rendah, mampu tumbuh pada substrat dengan potensial osmotik cukup tinggi dan sporulasi pada kelembaban relatif rendah (Rahman, 1989)

Enzim mempunyai kekhasan yaitu hanya bekerja pada satu reaksi saja. Suatu enzim mempunyai ukuran yang lebih besar dari pada substratnya. Oleh karena itu tidak seluruh bagian enzim dapat berhubungan dengan substrat, bagian enzim yang mengadakan hubungan dengan substrat disebut bagian aktif. (Poedjiadi, 1994).

\section{Metode}

\section{A. Alat dan bahan}

Cawan petri, Erlenmeyer, gelas ukur $100 \mathrm{~mL}$, beaker glass, tabung reaksi berfungsi, pipet ukur, neraca analitik, mikropipet, propipet, pipet volum $10 \mathrm{~mL}$, sendok, jarum ose, autoklaf, kamera digital, vortex, hot plate, oven, Bunsen,water bath, bungkil kesambi, Aspergillus niger M1407 yang diambil dari isolat biji kesambi, PDA, aquades, olive oil, $\mathrm{NaNO}_{3}, \mathrm{NaOH}$, Methanol, Etanol, Asam Oleat, fenolftalein, Isooktan.

\section{B. Metode Penelitian}

\section{Peremajaan Isolat Aspergillus niger M1407}

Isolat lipase A.niger diinokulasi pada medium PDA. Medium PDA dibuat dengan cara melarutkan 4,7 gram PDA dalam aquades $120 \mathrm{ml}$. PDA yang telah larut tersebut dipanaskan dengan hot plate, kemudian disterilkan dalam autoklaf dengan suhu $121^{\circ} \mathrm{C}$ selama 15 menit. Medium PDA tersebut maka semakin tinggi aktivitas lipase sampai pada suatu batas tertentu yang dapat 
sudah dingin, selanjutnya dilakukan inokulasi lipase Aspergillus niger M1407 (Ledo dkk., 2016).

\section{Fermentasi Solid State Tepung Kesambi}

Medium (25 gramTepung kesambi, aquades steril sebanyak $10 \mathrm{~mL}, \mathrm{NaNO}_{3}$, sebanyak 0,2 gram, olive oil $1 \mathrm{~mL}$ ) kemudian ditambahkan $5 \mathrm{~mL}$ A.nigerM1407 dari seripengenceran $10^{7}$, kemudian homogenkan agar medium dan inokulum A. niger M1407, kemudian tempat medium ditutup rapatdan dibiarkan selama 7 hari (Ledo dkk., 2016).

3. Ekstraksi Lipase Aspergillus niger M1407 dari Medium Solid State Fermentasi

1 gram hasil fermentasi solid state, ditambahkan $5 \mathrm{~mL}$ buffer fosfat $\mathrm{pH} 8$ :

0,1 M kemudian dishaker selama 30 menit, disaring dan disentrifuge kemudian mendapatkan super natan ekstrak kasar lipase A.nigerM1407(Hidayat dkk., 2015).

\section{KarakterisasiEkstrak KasarLipase Aspergillus niger M1407}

a. Karakterisasi Substrat Ekstrak KasarLipase A.nigerM1407

1) Substrat asam oleat etanol

0,2 mL ekstrak kasar lipase A. niger M1407 dimasukan kedalam erlenmeyer dan ditambahkan $4 \mathrm{~mL}$ substrat $(0,5 \mathrm{M}$ asam oleat dan 0,5 $\mathrm{M}$ etanol dalam isooktan dengan perbandingan 1: 1 ) kemudian dishaker selama 30 menit dan dilakukan sebanyak 3 kali pengulangan (Hidayat dkk., 2015).

2) Substrat asam oleat metanol

0,2 mL ekstrak kasar lipase A. niger M1407 dimasukan kedalam erlenmeyer dan ditambahkan $4 \mathrm{~mL}$ substrat $(0,5 \mathrm{M}$ asam oleat dan 0,5 M metanol dalam isooktan dengan perbandingan 1: 1 kemudian dishaker selama 30 menit, dilakukan sebanyak 3 kali pengulangan (Hidayat dkk., 2015).

b. Pengaruh Suhu Ekstrak Kasar Lipase Aspergillus nigerM1407 Ekstrak kasar lipase A. niger M1407 sebanyak 0,2 ml dimasukan kedalam tabung reaksi kemudian diletakan pada water bath dengan variasi suhu $20,30,40,50$, dan $60^{\circ} \mathrm{C}$ selama 30 menit dan di tambahkan substrat $0,5 \mathrm{M}$ asam oleat dan 0,5 M metanol dalam isooktan dengan perbandingan 1: 1 dan kemudian didishaker selama 30 menit( masing - masing perlakuan suhu diulang sebanyak 3 kali) kemudian masing- masing diuji aktivitas lipolitik menggunakan motede titrasi (Hidayat dkk., 2015).

\section{Analisis Aktivitas Lipase dengan Metode Titrasi}

Larutan hasil perlakuan substrat dan variasi suhu ditambahkan 5 tetes fenolftalein $1 \%$ sebagai indikator dan dititrasi dengan menggunakan larutan $\mathrm{NaOH}$ 0,05 M. Titrasi dihentikan setelah campuran berubah menjadi merah muda.aktivitas lipase ditentukan dari volume $\mathrm{NaOH} 50 \mathrm{mM}$ setara dengan 100 unit aktivitas lipase (Lestari dkk.,2009).

Unit aktivitas enzim dihitung dengan $=$

$$
\frac{\mathrm{V} \mathrm{NaOH} \text { sampel }-\mathrm{VNaOH} \text { kontrol }}{\text { bolume enzim }} \times 100(\mathrm{U} / \mathrm{mL})
$$

\section{Analisis Data}

Data yang diperoleh dalam penelitian ini dianalisis secara deskriptif kuantitatif.

\section{Hasil dan Pembahasan}

A.niger merupakan mikroorganisme yang dapat tumbuh dengan cepat. Penelitian ini dimulai dari solid state fermentationtepung kesambi. Aktivitas A.nigerM1407 maksimum pada waktu inkubasi 7 hari, kemudian di ekstraksi hasil solid state fermentation tepung kesambi tersebut menggunakan buffer fosfat $\mathrm{pH}$ 8. Tujuan untuk mendapatkan ekstrak kasar enzim lipase A.niger M1407. Proses dapat dilihat pada Gambar 1.

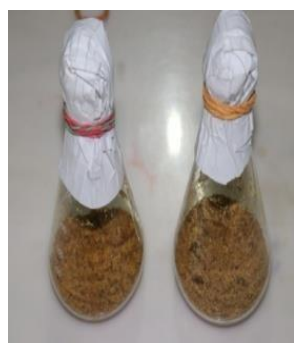

(a)

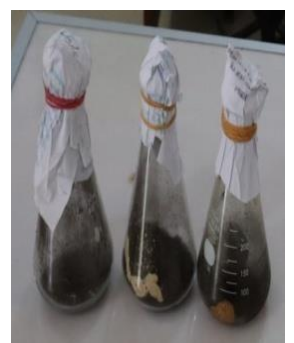

(b)

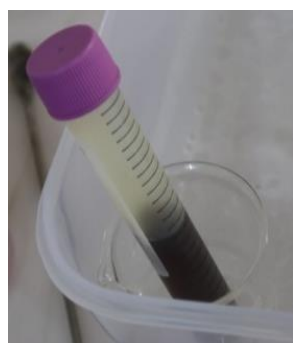

(c)
Gambar 1 Solid State FermentationTepung Kesambi Dan Ekstrak Kasar Lipase A.Niger M1407 (a) Sebelum Inkubasi., (b) Sesudah Diinkubasi., (c) Ekstrak Kasar Lipase(Salmon, 2019).

\section{A. Karakterisasi Substrat Ekstrak Kasar Lipase A.niger M1407} Menggunakan Etanol dan Metanol

Dalam penelitian ini dilakukan karakterisasi substrat dengan menggunakan substrat etanol dan metanol, karakterisasi substrat ekstrak kasar lipase A. niger M1407, di sajikan pada tabel 3.1 dibawah ini.

Tabel 1 Karakterisasi Substrat Ekstrak Kasar Lipase A. niger M1407

\begin{tabular}{|l|l|}
\hline No & \multicolumn{1}{c|}{$\begin{array}{c}\text { Subtrat } \\
\text { Satuan } \mathbf{U} / \mathbf{m L}\end{array}$} \\
\hline 1 & Asam oleat + etanol dalam isooktan 50 \\
\hline 2 & Asam oleat + methanol dalam isooktan \\
\hline
\end{tabular}

Tabel 1 menunjukan bahwa hasil karakterisasi substrat ekstrak kasar lipase $A$. niger M1407, asam lemak bebas yang bereaksi dengan asam oleat dalam metanol lebih tinggi yaitu dibandingkan dengan asam oleat dalam etanol. Semakin pendek rantai $\mathrm{C}$ pada alkohol akan lebih bereaksi dengan asam lemak tak jenuh (asam oleat) yang memiliki satu ikatan rangkap, sehingga metanol lebih mudah bereaksi dengan substrat dibandingkan dengan etanol(Gubitz dkk., 1999).

\section{B. Karakterisasi Suhu Lipase A. Niger M1407}

Dalam penelitian ini dilakukan variasi suhu untuk mengetahui pengaruh terhadap aktivitas lipase A. niger M1407 yaitu $20^{\circ} \mathrm{C}, 30^{\circ} \mathrm{C}, 40^{\circ} \mathrm{C}, 50^{\circ} \mathrm{C}$, dan $60^{\circ} \mathrm{C}$ Karakterisasi suhu ekstrakkasar lipaseA.niger M1407 dapat dilihat pada Gambar 2 .

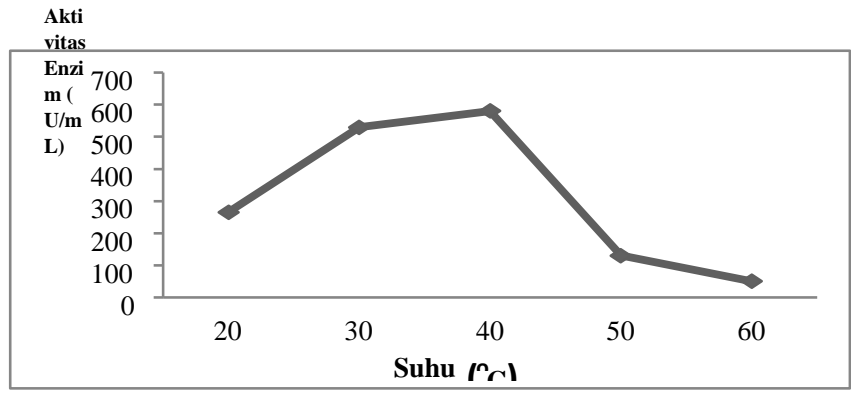

Gambar 2 Karakterisasi Suhu Terhadap Aktivitas Lipase A. niger M1407 Kenaikan aktivitas ekstrak kasar lipase A.niger M1407 terjadi pada suhu $30^{\circ} \mathrm{C}$ dan $40^{\circ} \mathrm{C}$ presentase penghitungan aktivitas ekstrak kasar lipase meningkat dari suhu $20^{\circ} \mathrm{C}$ ke suhu $30^{\circ} \mathrm{Csebesar} 50 \%$ kemudian dari suhu $30^{\circ} \mathrm{C}$ ke suhu $40^{\circ} \mathrm{C}$ penambahan aktivitas lipase A.niger M1407 meningkat mencapai8,63\%,kemudian pada suhu yang ke $50^{\circ} \mathrm{C}$ aktifitas ekstrak kasar lipase A. niger M1407 menurun drastis sebesar77,59\% dan pada suhu $60^{\circ} \mathrm{C}$ terjadi penurunuan aktivitas lipase sebesar38,46\%, aktivitas lipase menurun seiring dengan kenaikan suhu, pencapaian aktivitas lipase yang terendah berada pada suhu $60^{\circ} \mathrm{C}$ yang merupakan suhu tertinggi pada penelitian ini (Gambar 3.1).Hal ini dikarenakan enzim lipase mengalami kerusakan pada suhu yang lebih tinggi. Enzim merupakan protein, maka suhu tinggi dapat menyebabkan denaturasi protein. Pengaruh suhu juga akan diakibatkan oleh adanya struktur tiga dimensi 
enzim yang sensitif terhadap suhu dan tidak menjadi stabil pada suhu yang tinggi yang tidak sesuai dengan suhu optimumnya (Murni dkk., 2011)

Tabel 2 Perbandingan Suhu Optimum Aktivitas Lipase Dari Beberapa Sumber Lipase

\begin{tabular}{|c|c|c|c|}
\hline No & Suhu Optimum & Sumber Lipase & Media Tumbuh \\
\hline 1 & $40^{\circ} \mathrm{C}$ & $\begin{array}{l}\text { Aspergillus niger } \\
\text { M14017 }\end{array}$ & $\begin{array}{l}\text { Biji kesambi } \\
\text { Salmon, } 2019\end{array}$ \\
\hline 2 & $40^{\circ} \mathrm{C}$ & $\begin{array}{l}\text { Aspergillus niger } \\
6516\end{array}$ & $\begin{array}{l}\text { Biji jarak } \\
\text { Hidayat dkk., } 2015\end{array}$ \\
\hline 3 & $40^{\circ} \mathrm{C}$ & $\begin{array}{ll}\text { Aspergillus } & \text { niger } \\
\text { PAM 18A } & \\
\end{array}$ & $\begin{array}{l}\text { Tanah } \\
\text { Ramadhani dkk.,2015 }\end{array}$ \\
\hline 4 & $30^{\circ} \mathrm{C}$ & $\begin{array}{l}\text { Aspergillus niger } \\
\text { G783 }\end{array}$ & $\begin{array}{l}\text { Bungkil kedela Jia } \\
\text { dkk., } 2015\end{array}$ \\
\hline 5 & $30^{\circ} \mathrm{C}$ & $\begin{array}{l}\text { Aspergillus } \text { niger } \\
\text { NCIM } 1207\end{array}$ & $\begin{array}{l}\text { Dedak gandum } \\
\text { Silva dkk., } 2008 \\
\end{array}$ \\
\hline 6 & $35^{\circ} \mathrm{C}$ & $\begin{array}{l}\text { Aspergillus } \\
\text { MYA } 135\end{array}$ & $\begin{array}{l}\text { Minyak zaitun } \\
\text { Romero dkk., } 2007\end{array}$ \\
\hline 7 & $40^{\circ} \mathrm{C}$ & $\begin{array}{l}\text { Aspergillus niger } \\
\mathrm{J}-1\end{array}$ & $\begin{array}{l}\text { Biji gandum } \\
\text { Gwen dkk,2006 }\end{array}$ \\
\hline 8 & $45^{\circ} \mathrm{C}$ & Aspergillus flavus & $\begin{array}{l}\text { Ubi jalar Omar dan } \\
\text { Schloder, } 1996\end{array}$ \\
\hline
\end{tabular}

Perbandingan suhu optimum aktivitas lipase dari beberapa sumber lipase dengan aktivitas enzim tertinggi pada $A$. flavus dengan suhu optimum $45^{\circ} \mathrm{C}$ dan aktivitas enzim $600 \mathrm{U} / \mathrm{mL}$ dan A.nigerM14017 dengan suhu optimum $40^{\circ} \mathrm{C}$ dan aktivitas enzim $580 \mathrm{U} / \mathrm{mL}$. Enzim sangat sensitif terhadap suhu apabila suhunya dibawah suhu optimum memran selnya kaku, dan diatas suhu optimum memran sel mengalami denaturasi.

Faktor utama yang mempengaruhi aktivitas enzim salah satunya adalah suhu. Suhu sangat menentukan akvitas enzim pada waktu mengkatalisa suatu reaksi. Seluruh enzim memerlukan suhu tertentu untuk dapat aktif. Sejalan dengan meningkatnya suhu, makin meningkat pula aktivitas enzim, aktivitas enzim meningkat hingga mencapai kondisi suhu optimum.

\section{Simpulan}

Substrat yang lebih baik ada pada substrat asam oleat metanol memiliki aktivitas lipase 200 U/mL.Dan Aktivitas lipase A.niger M1407pada karakerisasi suhu lipase A. niger M1407 memiliki aktivitas optimum pada suhu $40^{\circ} \mathrm{C}$.

\section{Pustaka}

Aziz, P. 2012. Enzim dan Faktor-faktor yang mempengaruhi Laju Reaksi Enzim. Addtion material for FIK Biochemical Experiment Class. Diakses tanggal 15 April 2012.

Gandjar, I., Robert, A.S., Karin van den, T. V ., Ariyati, O., dan Iman, S. 1999.Mengenali Kapang Tropik Umum. Yayasan Obor Indonesia. Jakarta.

Gubitz, G.M., M.Mittelbach dan M.Trabi. 1999. Exploitation of the tropical seed plant Jatropha curcas L., Bioresource Technology.

Hidayat, C. Darmasiwi, S. Nurikasari, M. 2015. Characterization of AspergillusNiger 65 i6 lipase fromsolid-state fermentation using Jatrophaseed cake medium.Insdonesian journal of Biotechnology. Vol. (2) pp. 108-116.Yogyakarta.

Ledo, S.E. Mellissa, Dima, R. Yemima, Nope, V.V. Jumita. 2016. Aktivitas Lipolitik Aspergillus niger dan penicillum sp Indigenius yang diisolasi dari Biji Kesambi (schleichera oleosa). Prosiding seminar nasional sainstek ke-3.28-29 Oktober 2016. UNDANA. Kupang.

Lestari, P.,Handayani, S.N. dan Oedjijono. 2009. Sifat-sifat Biokimiawi Ekstrak Kasar Lipase Ekstraseluler Dari Bakteri Azospirillum sp. JG3. Program Studi Kimia, Jurusan MIPA Fakultas Sains dan Teknik UNSOED, Purwokerto Fakultas Biologi UNSOED. Purwokerto.

Masfufatun. 2010. Isolasi dan Karakterisasi Enzim Selulase.(Skripsi) Fakultas Kedokteran Universitas Wijaya Kusuma. Surabaya.

Murni,W. Sri, Kholisoh, D. Siti, L.D. Tanti, M. E. Petrissia. 2011. Produksi, Karakterisasi, dan Isolasi Lipase dari Aspergillus niger. Prosiding seminar nasionl teknik kimia, pengembangan teknologi kimia untuk pengolahan Sumber Daya Alam Indonesia. Program Studi Kimia Fakultas Teknologi Industri. ISSN 1693-4393.

Nurosid.,Oedjijono.danLestari,P.2008.Kemampuan Azospirillum sp.JG3 Dalam Menghasilkan Lipase Pada Medium Campuran Dedak Dan Onggok Dengan Waktu Inkubasi Berbeda.Departement of Microbiologi, Biology Faculty Jenderal Soedirman University.Purwokerto.

Rahman, A. 1989. Teknologi fermentasi industrial. Bogor. Institut Pertanian Bogor. Winarno, F.G. 1989. Enzim Pangan. Garamedia Press. Jakarta. 